\title{
PENGARUH PENDEKATAN INTERACTIVE CONCEPTUAL INSTRUCTION (ICI) BERBANTUAN SIMULASI PHET TERHADAP HASIL BELAJAR SISWA
}

\author{
Ega Prastika*, Andik Purwanto, Nirwana
}

\author{
Program Studi Pendidikan Fisika, Fakultas Keguruan dan Ilmu Pendidikan, Universitas Bengkulu \\ Jl. WR. Supratman, Kandang Limun, Bengkulu \\ E-mail*: egaprastika08@gmail.com
}

\begin{tabular}{c|c|c|c}
\hline Diterima 19 Juli 2020 & Direvisi 19 Agustus 2020 & Disetujui 21 Agustus 2020 & Dipublikasikan 31 Agustus 2020 \\
\hline \multicolumn{5}{c}{ https://doi.org/10.33369/jkf.3.2.141-150 } \\
\hline
\end{tabular}

\begin{abstract}
ABSTRAK
Penelitian ini bertujuan untuk mendeskripsikan pengaruh pendekatan (ICI) berbantuan simulasi PhET terhadap hasil belajar, dan menentukan besar pengaruh pendekatan (ICI) berbantuan simulasi PhET terhadap hasil belajar. Penelitian ini dilakukan terhadap siswa-siswi kelas X MIPA di SMAN 09 Kota Bengkulu. Materi pelajaran yang dibahas adalah hukum newton gravitasi. Metode yang digunakan pada penelitian ini adalah kuasi eksperimen dengan desain penelitian nonequivalent control group design. Pengajaran dengan pendekatan ICI berbantuan simulasi PhET digunakan sebagai kelas eksperimen dan pengajaran dengan cara tanpa pendekatan ICI berbantuan simulasi PhET sebagai kelas kontrol. Instrument yang digunakan pada penelitian ini adalah soal tes untuk hasil belajar siswa. Hasil belajar siswa diukur menggunakan uji-t untuk mendeskripsikan hasil pretest dan posttest pada kelas eksperimen dan kelas kontrol. Untuk mencari besar pengaruh pendekatan ICI berbantuan simulasi PhET digunakan effect size. Hasil penelitian menunjukan bahwa dari perbandingan nilai sig.(2-Tailed) dengan uji independent t test antara pretest kelas kontrol dan eksperimen sebesar 0.490 artinya tidak terdapat perbedaan dan posttest kelas control dan eksperimen sebesar 0,001 terdapat perbedaan atau ICI berpengaruh terhadap hasil belajar, dengan besar pengaruh yaitu 0,78 atau ICI berbantuan simulasi PhET memberikan pengaruh sebesar $43 \%$ pada satu kali pertemuan. Dapat disimpulkan bahwa terdapat pengaruh Interactive conceptuan ictruction (ICI) berbantuan simulasi PhET terhadap hasil belajar siswa sebesar $43 \%$.
\end{abstract}

Kata Kunci: Interactive Conceptual Instruction (ICI), Simulasi PhET, Hasil Belajar Siswa

\begin{abstract}
The aims of this research was to describe the effect of a PhET-assisted simulation approach (ICI) on learning outcomes, and was to determine the influence of PhET's simulation assisted approach (ICI) on learning outcomes. This research was conducted on students of class X MIPA in SMAN 09 Bengkulu city. The subject matter discussed was Newton's law of gravity. The method used in this research was the quasi experiment with the design of non-equivalent control group design research. Instruction with the PhET-assisted ICI simulation approach was used as a class of experimentation and teaching in a way that does not approach the PhET simulation as a control class. The Instrument used in this research is the test for students ' learning outcomes. The students learning results were measured using test-t to describe the results of pretests and post test in experimental class and control class. To find a great influence on the approach of ICI assisted simulation PhET was used effect size. The result showed that from the comparison of the value of SIG. (2-Tailed) with test independent $\mathrm{T}$ Test between control class pretest and experimentation of 0490 means there was no difference and post test class control and experimentation of 0.001 there are differences or ICI has 43 an effect on learning outcomes, with a big influence of 0.78 or a simulated assisted It can be concluded that there is the influence of Interactive Conceptuan Ictruction (ICI) assisted PhET simulation of students ' learning outcomes of $43 \%$.
\end{abstract}

Key words: Interactive Conceptual Instruction (ICI), PhET simulation, student learning outcomes

\section{PENDAHULUAN}

Undang-Undang No 20 tahun 2003 tentang sistem pendidikan nasional, menyatakan bahwa "Pendidikan merupakan usaha agar manusia dapat mengembangkan potensi dirinya melalui proses 
pembelajaran dan/atau cara lain yang dikenal dan diakui oleh masyarakat". Pendidikan kunci utama persiapan sumber daya manusia (SDM) untuk memetik kemenangan dalam era globalisasi. Pendidikan juga membimbing anak mencapai tahap kedewasaan supaya anak tersebut dapat melaksanakan tugas hidup dengan baik tanpa bantuan dari orang lain. Guru memiliki tanggung jawab untuk membimbing peserta didik dalam mencapai tujuan pendidikan yang diinginkan.

Pendidikan merupakan sebuah sistem. Sebagai sistem, aktivitas pendidikan terbangun dalam beberapa komponen, yaitu pendidik, peserta didik, tujuan pendidikan, alat pendidikan, dan lingkungan pendidikan (1). Guru dan peserta didik merupakan faktor penentu yang sangat dominan dalam pendidikan umumnya, karena guru dan peserta didik memegang peranan dalam proses pembelajaran (2) Adapun faktor yang menjadi penentu proses pembelajaran antara lain tujuan pendidikan, materi pendidikan, metode pendidikan, alat pendidikan dan lingkungan. Untuk menjawab tantangan dan persoalan yang dihadapi bangsa indonesia dala era globalisasi perlu adanya kebijakan baru pemerintah dalam bidang pendidikan. Sehingga dapat membawa perubahan besar dalam pelaksanaan, dan implementasi kurikulum. Hal ini dilakukan pada tingkat satuan pendidikan mulai dari sekolah dasar, sekolah menengah pertama, dan sekolah menengah atas atau sekolah menengah kejuruan. Kurikulum merupakan salah satu komponen yang memiliki peran penting dalam sistem pendidikan, sebab dalam kurikulum bukan hanya dirumuskan tentang tujuan yang harus dicapai, tetapi memperjelas arah pendidikan, yang dapat memberikan pemahaman tentang pengalaman belajar yang dimiliki siswa (3)

Kurikulum diharapkan dapat menyeimbangkan aspek kognitif, aspek afektif, dan asfek psikomotor, sehingga dari ketiga aspek tersebut proses pembelajaran yang dilakukan dapat berimbang, tidak hanya cenderung mengutamakan aspek kognitif saja. Kurikulum 2013 di susun dengan maksud antara lain untuk mengembangkan potensi peserta didik menjadi kemampuan dalam berfikir reflektif dalam menyelesaikan masalah sosial di masyarakat. Kurikulum 2013 dikembangkan dengan penyempurnaan pola pikir dari pembelajaran pasif menjadi pembelajaran kritis, pola pelajaran yang semula berpusat pada guru menjadi pelajaran yang berpusat pada peserta didik dan yang semula satu arah menjadi pembelajaran Interaktif (4). Pembelajaran yang terjadi akibat implementasi dari kurikulum 2013 ini adalah proses pembelajaran tidak lagi berpusat pada guru, melainkan berpusat pada aktivitas siswa. Guru sebagai pembimbing atau fasilitator untuk merancang pembelajaran agar siswa dapat menyelesaikan permasalahan kontekstual maupun nyata, dalam proses pembelajaran yang bersifat interaktif.

Beberapa hal perlu diperhatikan oleh guru dalam memilih model dan metode pembelajaran yaitu karakteristik materi, karakteristik siswa sarana dan prasarana serta kemampuan guru itu sendiri, setiap siswa memiliki karakteristik yang berbeda-beda sehingga perlu dibimbing secara bertahap sesuai dengan karakteristiknya masing-masing, sehingga dapat meningkatkan hasil belajar. Pendidikan mempunyai tugas menyiapkan sumber daya manusia untuk pembangunan. Langkah pembangunan selalu diupayakan seirama dengan tuntutan zaman. Perkembangan zaman selalu memunculkan tantangan-tantangan baru, yang sebagian sering tidak dapat diramalkan sebelumnya (5). Salah satu permasalahan yang sering dihadapi dalam dunia pendidikan di Indonesia pada saat ini adalah mutu pendidikan yang rendah pada setiap jenjang dan satuan pendidikan, oleh karena itu melalui pengembangan kurikulum nasional maupun lokal sejalan dengan kemajuan perkembangan ilmu pengetahuan dan teknologi (IPTEK) dan era globalisasi yang menuntut adanya reformasi dalam bidang pendidikan pada peningkatan manajemen sekolah untuk meningkatkan kualitas sumber daya manusia. Belajar dimaknai sebagai proses perubahan perilaku sebagai hasil interaksi individu dengan lingkungannya. Perubahan perilaku terhadap hasil belajar bersifat continiu, fungsional, positif, aktif, dan terarah (6) .

Hasil belajar atau pembelajaran merupakan nilai yang diberikan oleh guru dari metode (strategi) alternatif dalam kondisi yang berbeda (7). Pemahaman konsep terutama konsep fisika tidak hanya sekedar mengetahui konsep-konsep fisika saja, melainkan benar-benar memahaminya dengan baik yang ditunjukan oleh kemampuannya dalam menyelesaikan permasalahan, baik yang terikat dengan konsep maupun penerapannya dalam kehidupan sehari-hari dalam situasi baru. Setelah melakukan observasi di SMAN 09 Kota Bengkulu, ada beberapa hal yang didapat terutama

Pengaruh Pendekatan Interactive Conceptual Instruction (Ici) Berbantuan Simulasi Phet Terhadap Hasil Belajar Siswa Di Sman 9.... Ega Prastika, Andik Purwanto, Nirwana 
dalam dalam proses pembelajaran yang kurang efektif dan kurang menarik, itu karena siswa belum mampu menyerap kurikulum yang diterapkan oleh guru mata pelajaran, siswa masih cenderung belum mampu menyelesaikan masalah secara individu maupun kelompok, siswa masih menjadikan guru sebagai sumber belajar utama, siswa kurang mampu menggunakan teknologi yang ada, menyebabkan kurangnya minat belajar siswa, mengakibatkan siswa cenderung tidak memperhatikan dan sibuk dengan kegiatan masing-masing. Adanya kekurangan pada alat praktikum di laboratorium fisika mengakibatkan siswa kurang memahami konsep dengan baik.

Pemahaman konsep mekanika membutuhkan proses-proses interaktif dalam pembelajaran. Proses ini merupakan proses yang harus dilewati oleh guru dan siswa untuk memikirkan dan membicarakan sebuah gagasan atau konsep yang dilakukan secara interaktif. Dengan kata lain, konsekuensi dari pembelajaran ini adalah dialog dalam mengajar dan belajar harus berkelanjutan. Pendekatan yang telah dikembangan untuk penpelajaran interaktif dan meningkatkan pemahaman konsep siswa adalah pendekatan Interactive Conceptual Instruction (ICI) (8). PhET merupakan akronim dari Physics Education Technology yang merupakan sebuah simulasi interaktif mengenai fenomena-fenomena fisis berbasis riset yang berupa software. Simulasi PhET ini diciptakan oleh universitas Colorado yang di dalamnya terdapat simulasi-simulasi pembelajaran IPA (9).

ICI pertama kali digunakan dalam sebuah penelitian untuk mengevaluasi metode pembelajaran interaktif pada konsep mekanika dengan menggunakan FCI untuk memantau pembelajaran siswa, hasil penelitian menunjukan bahwa penggunaan pendekatan ICI, secara signifikan dapat meningkatkan pemahaman konsep mekanika siswa dibanding penggunaan pembelajaran tradisional. Penelitian lain yang telah dikembangan baru-baru ini adalah menggunakan pendekatan Interactive Conceptual Instruction (ICI) untuk meningkatkan pemahaman konsep usaha dan energi dengan menggunakan komik pembelajaran, hasil penelitian menunjukan bahwa ICI memiliki pengaruh yang kuat dalam meningkatkan pemahaman konsep usaha dan energi siswa SMA ditunjukkan oleh perolehan nilai pengaruh sebesar 1.56 (10). Penelitian mengenai efektivitas penggunaan media simulasi virtual pada pendekatan pembelajaran konseptual interaktif yang bertujuan untuk meningkatkan pemahaman konsep dan meminimalkan miskonsepsi. Hasil penelitian dengan penggunaan media simulasi virtual terbukti dapat lebih meningkatkan efektivitas pendekatan pembelajaran konseptual dalam meningkatkan pemahaman konsep dan meminimalkan kuantitas miskonsepsi (11).

Dengan melihat hasil penelitian yang telah dilakukan dan berdasarkan permasalahpermasalahan di sekolah, kemudian dilakukan penelitian dengan menggunakan pendekatan Interactive Conceptual Instruction. Berdasarkan uraian diatas yang menjadi rumusan masalah dalam penelitian ini yaitu: 1) Bagaimana pengaruh pendekatan Interactive Conceptual Instruction berbantuan simulasi PhET terhadap hasil belajar? 2) Berapa besar pengaruh pendekatan Interactive Conceptual Instruction berbantuan simulasi PhET terhadap hasil belajar?

\section{METODE PENELITIAN}

Penelitian yang dilaksanakan adalah penelitian kuasi eksperimen untuk mengetahui pengaruh pendekatan ICI berbantuan simulai PhET terhadap hasil belajar siswa dengan desain yang digunakan adalah desain penelitian nonequivalent control group design. Desain ini hampir sama dengan pretest-posttest control group design, hanya pada desain ini kelompok eksperimen maupun kelompok kontrol tidak dipilih secara random

Tabel 1. Desain Penelitian Nonequivalent Control Group Desain

\begin{tabular}{cccc}
\hline Kelompok & Pretest & Perlakuan & Posttest \\
\hline Eksperimen & $\mathrm{O}_{1}$ & $\mathrm{X}_{1}$ & $\mathrm{O}_{2}$ \\
Control & $\mathrm{O}_{3}$ & $\mathrm{X}_{2}$ & $\mathrm{O}_{4}$ \\
\hline
\end{tabular}

Pada tabel di atas dapat dijelaskan bahwa kelompok sampel (kelas eksperimen) yang diajarkan dengan pembelajaran menggunakan pendekatan Interactive Conceptual Instruction berbantuan simulasi PhET. Kelompok sampel (kelas kontrol) yang diajarkan dengan pembelajaran 
konvensional. Keterangan : $\mathrm{O}_{1}$ : Pretest kelas eksperimen (X), $\mathrm{O}_{2}$ : Posttest kelas eksperimen (X), $\mathrm{O}_{3}$ : Pretest kelas kontrol, $\mathrm{O}_{4}$ : Posttest kelas kontrol, dan $\mathrm{X}$ : Perlakuan menggunakan model ICI.

Populasi dalam penelitian ini adalah seluruh siswa kelas X MIPA SMAN 09 Kota Bengkulu yang terdiri atas 3 kelas, X MIPA 1, X MIPA 2 dan X MIPA 3 dengan kurang lebih 23 siswa di setiap kelas. Pengambilan sampel dalam penelitian ini menggunakan teknik sampling purposive untuk variable tunggal, bebas dan terikat. Sampling purposive adalah teknik penentuan sampel dengan pertimbangan tertentu(12). Pada penelitian ini, yang yang mengambil pertimbangan adalah seorang guru mata pelajaran fisika kelas X di sekolah SMAN 09 Kota Bengkulu berdasarkan nilai ulangan harian siswa untuk penelitiankuasi eksperimen, selanjutnya di uji normalitas. Tes dalam penelitian ini dilakukan dua kali yaitu pretest (tes hasil belajar awal) dan posttest (tes hasil belajar akhir). Tes ini dilakukan untuk mengetahui hasil belajar anak sebelum dan sesudah diberikan pembelajaran menggunakan pendekatan ICI sehingga dapat diketahui ada tidaknya pengaruh pendekatan tersebut terhadap hasil belajar siswa.

Instrumen tes yang digunakan untuk mengumpulkan data akan dinilai terlebih dahulu oleh tiga orang ahli yaitu dua orang guru fisika dan satu dosen fisika dengan cara mencocokkan soal tes dengan indikator pada kisi-kisi butir tes. Tujuannya adalah untuk menentukan validitas isi. Tahapan validitas isi, yaitu 1) terlebih dahulu soal dikoreksi melalui penilaian dosen dan guru, 2) saran/koreksi dari dosen dan guru digunakan sebagai bahan revisi soal, dan 3) soal yang telah direvisi digunakan pada penelitian tiap siklusnya. Soal diuji coba lapangan terlebih dahulu kepada kelas yang telah belajar metaeri hukum newton gravitasi. Hasil uji coba ini akan digunakan untuk mengetahui validitas, tingkat kesukaran, daya pembeda soal, serta reliabilitas soal. Pengolahan data dan analisis data dalam penelitian ini dilakukan terhadap skor pretest dan skor posttest siswa. Pengolahan dan analisis data yang dilakukan meliputi analisis deskriptif dan analisis inferesial. Dari penelitian ini akan diperoleh empat data yaitu, $\mathrm{O}_{1}, \mathrm{O}_{2}, \mathrm{O}_{3}$, dan $\mathrm{O}_{4}$. Dimana $\mathrm{O}_{1}$ dan $\mathrm{O}_{2}$ adalah skor pretest dan skor posttest kelas eksperimen $\mathrm{X}$ dengan pendekatan Interactive Conceptual Instruction(ICI) sedangkan $\mathrm{O}_{3}$ dan $\mathrm{O}_{4}$ adalah skor pretest dan skor posttest kelas kontrol dengan model pembelajaran konvensional,

Analisis inferensial adalah teknik statistik yang digunakan untuk menganalisis data sampel dan hasilnya diberlakukan untuk populasi. Analisis inferensial dalam penelitian diguanakan untuk menganalisis data yang diperoleh dari hasil rata-rata pretest dan rata-rata posttest, yang kemudian digunakan untuk menguji hipotesis(13). Statistik inferensial terbagi menjadi analisis statistik parametris dan analisis statistik nonparametris. Untuk menentukan analisis statistik inferensial yang akan digunakan, sebelumnya data harus di uji normalitas dan uji homogenitas varians. Jika data keduanya memenuhi syarat berdistribusi normal dan variansnya homogen, maka akan digunakan analisis statistik parametris. Namun, jika data tidak normal atau jika data memiliki varians yang tidak homogen maka analisis data yang digunakan adalah analisis statistik nonparametris. Analisis parametrik digunakan dalam penelitian ini jika data yang diambil merupakan data yang berdistribusi normal dan homogeny dihitung menggunakan SPSS. Effect Size memenunjukan sejauh mana suatu variable mempengaruhi variable lain dalam suatu pene;itian atau menunjukan seberapa efektif suatu variable mempengaruhi variable lainnya. Effect Size dapat dihitung dengan formulasi Cohen, (1998) dan kemudian dijabarkan lebih rinci oleh Hake (2002)(14)

$$
d=\frac{\left(M_{A}-M_{B}\right)}{\left[\left(S d_{A}^{2}+S d_{B}^{2}\right) / 2\right]^{1 / 2}}
$$

dengan d adalah Effect Size, $\mathrm{M}_{\mathrm{A}}$ adalah nilai rata-rata kelas eksperimen, $\mathrm{M}_{\mathrm{B}}$ adalah nilai rata-rata kelas control, $\mathrm{Sd}_{\mathrm{A}}$ adalah simpangan baku atau standar deviasi kelas eksperimen, $\mathrm{Sd}_{\mathrm{B}}$ adalah simpangan baku atau standar deviasi kelas control.

\section{HASIL DAN PEMBAHASAN}

Penelitian ini telah dilaksanakan di SMAN 09 Kota Bengkulu pada tanggal 16 dan 17 Maret 2020. Penelitian ini dilaksanaakan bersamaan dengan wabah virus yang hampir terjadi diseluruh dunia disebut dengan corona virus 2019 (covid19) yang mangakibatkan sekolah dan universitas 
baik negeri maupun swasta diliburkan sementara waktu untuk mencegah penularan covid19 diindonesia oleh karena itu penelitian hanya dilakukan 1 kali pertemuan kelas control dan kelas eksperimen pada minggu pertama sebelum sekolah diliburkan, ini mengakibatkan kurangnya data yang didapat oleh peneliti. Populasi penelitian adalah siswa kelas X yang terdiri dari X MIPA 1, X MIPA 2 dan X MIPA 3 pada tahun ajaran 2019/2020. Pengambilan sampel pada penelitian ini menggunakan teknik sampling purposive. Teknik sampling purposive pada penelitian ini adalah teknik penentuan sampel dengan pertimbangan tertentu melalui pertimbangan yang diberikan oleh guru mata pelajaran fisika. Sampel penelitian adalah kelas X MIPA 1 yang berjumlah 24 orang siswa dan kelas X MIPA 2 yang berjumlah 23 orang siswa.

Kelas sampel yang dipilih sebagai objek penelitian untuk hasil belajar dilakukan teknik sampling purposive atau melalui pertimbangan yang diberikan oleh guru mata pelajaran fisika. Lalu diuji homogenitas varians dan uji normalitas melalui nilai ulangan harian siswa dan hasilnya kedua kelas bersifat homogeni dan normal. Sehingga uji beda menggunakan analisis parametric uji $\mathrm{t}$ dan hasilnya tidak dapat perbedaan nilai ulangan harian siswa dari kelas X MIPA 1 dan X MIPA 2, sehingga penelitian ini dapat dilanjutkan pada kelas sampel yaitu kelas X MIPA 2 sebagai kelas eksperimen dan X MIPA 1 sebagai kelas kontrol. Kelas eksperimen diberi perlakuan dengan penggunaan pendekatan Interactive Conceptual Instruction berbatuan simulai PhET, sedangkan kelas kontrol diberikan pembelajaran dengan model konvensional. Hasil uji coba dianalisis menggunakan uji validitas, uji reliabilitas, uji tingkat kesukaran dan uji daya pembeda soal masingmasing pertemuan.

Tabel 2. Hasil Uji Coba Instrumen Tes Pertemuan 1

\begin{tabular}{cccccccc}
\hline \multicolumn{2}{c}{ Uji coba } & Validitas & $\begin{array}{c}\text { Tingkat } \\
\text { kesukaran }\end{array}$ & \multicolumn{2}{c}{ Daya pembeda } & Reliabilitas \\
\hline \multirow{2}{*}{$\begin{array}{c}\text { Pertemuan } \\
\mathbf{1}\end{array}$} & Nomor soal & $1,2,3$ & $1,2,3$ & 1 & 2 & 3 & \\
& Interpretasi & Valid & Sedang & Baik & cukup & jelek & 0,4 (cukup) \\
& Jumlah soal & 3 & 3 & 1 & 1 & 1 & \\
\hline
\end{tabular}

Berdasarkan Tabel 2 uji coba instrumen tes hasil belajar siswa yang telah dilakukan diperoleh bahwa soal tes yang digunakan pada pertemuan pertama yang diujicobakan adalah valid, dengan tingkat kesukaran soal sedang dan untuk daya pembeda soal masing masing memiliki interpretasi baik, cukup dan jelek. Untuk uji reliabilitas diperoleh koefisien reliabilitas pada pertemuan pertama adalah 0,4. Berdasarkan hasil hitungan menggunakan spss yang berarti bahwa soal reliabel dalam kategori cukup. Pada penelitian ini data deskripsi diperoleh menggunkan hitungan spsss pada tes Hasil Belajar Siswa yang dilakukan pada kelas eksperimen dan kelas control, data dapat dilihat dari tebel 3 berikut

Tabel 3. Deskripsi Data Tes Hasil Belajar.

\begin{tabular}{|c|c|c|c|c|c|}
\hline \multicolumn{6}{|c|}{ Descriptive Statistics } \\
\hline & $\mathrm{N}$ & Minimum & Maximum & Mean & $\begin{array}{c}\text { Std. } \\
\text { Deviation }\end{array}$ \\
\hline Pretest Eksperimen & 23 & 13 & 53 & 33.22 & 11.94 \\
\hline $\begin{array}{c}\text { Posttest } \\
\text { Eksperimen }\end{array}$ & 23 & 50 & 93 & 77.52 & 11.06 \\
\hline Pretest Kontrol & 24 & 14 & 50 & 30.96 & 10.26 \\
\hline Posttest Kontrol & 24 & 43 & 90 & 68.13 & 12.72 \\
\hline Valid N (listwise) & 23 & & & & \\
\hline
\end{tabular}

Berdasarkan Tabel 3 dapat dilihat bahwa pretest kelas eksperimen dengan jumlah siswa 23 orang memiliki nilai minimum sebesar 13, maksimum sebesar 53 dengan rata-rata sebesar 33.22, posttest nilai minimum siswa sebesar 50, nilai maksimum sbesar 93 dengan rata-rata nilai sebesar 77,52 , sedangan untuk pretes kelas control dengan jumlah siswa 24 orang didapat nilai minimum 
sebesar 14, nilai maksimum 50 dengan rata-rata nilai sebesar 30,96, posttest kelas control nilai minimum siswa sebesar 43, nilai maksimum sebesar 90 dengan rata-rata sebesar 68,13.

Pengujian hipotesis dicari dengan menggunakan uji Independen Sample t test polled varian menggunakan spss, dalam hal ini digunakan untuk mengetahui perbedaan rata-rata dua sample yang tidak berpasangan hasil belajar siswa pada kelas eksperimen yang diberi perlakuan dengan pendekatan Interactive Conceptual Instruction dengan kelas kontrol yang diberi perlakuan dengan model konvensional. Dari data yang telah diuji sebelumnya didapat bahwa skor rata-rata pretest dan posttest kedua kelas dinyatakan normal dan homogen sehingga dapat dilanjutkan pengujian dengan statistik parametris (uji Independent Sample T Test). Pengujian hipotesis statistik dapat dilihat pada tabel 4. berikut:

Tabel 4. Uji Independen Sample t test

\begin{tabular}{ccccccc}
\hline & Kelas & N & Mean & Sig. (2-Tailed) & $\begin{array}{c}\text { Signifikansi } \\
\mathbf{5 \%}\end{array}$ & Kesimpulan \\
\hline \multirow{2}{*}{ Pretest } & Eksperimen & 23 & 33.22 & 0.490 & 0,05 & Tidak Berbeda \\
& Kontrol & 24 & 30.96 & & & Signifikan \\
\multirow{2}{*}{ Postest } & Eksperimen & 23 & 77.52 & 0.010 & 0,05 & $\begin{array}{c}\text { Berbeda } \\
\text { Kontrol }\end{array}$ \\
& 24 & 68.13 & & & Signifikan \\
\hline
\end{tabular}

Berdasarkan Tabel 4 dapat diketahui bahwa rata-rata skor pretest hasil belajar antara kelas eksperimen dan kelas kontrol tidak berbeda signifikan dikarenakan nilai sig.(2-taited) $<5 \%$ sebesar $0.490<0,05$. Hal ini menunjukkan bahwa kemampuan awal siswa kelas eksperimen dan kelas kontrol sebelum diberi perlakuan adalah sama. Sedangkan pada hasil posttest skor rata-rata kelas eksperimen meningkat atau lebih tinggi dari pada kelas kontrol, diperoleh nilai sig.(2-taited) sebesar 0,010<0,05 dengan kesimpulan diperoleh bahwa berbeda signifikan atau terdapat perbedaan yang signifikan hasil belajar dengan pendekatan Interactive Conceptual Instruction berbatua simulai PhET di SMAN 09 Kota Bengkulu pada semester genap kelas X SMA.

Pada penelitian ini digunakan juga uji lanjutan Effect Size untuk mengetahui besarnya pengaruh pendektan interactive conceptual intruction berbantuan simulai PhET terhadap hasil belajar siswa. Diperoleh besar pengaruh pendekatan Interactive Conceptual Instruction terhadap hasil belajar sebesar 0,78 artinya ICI memberikan pengaruh sebesar $43 \%$ terhadap hasil belajar. Penelitian yang dilakukan pada kelas eksperimen sama halnya dengan pembelajran yang sering dilakukan di SMAN 09 Kota Bengkulu hanya saja pada penelitian ini diberikan perlakuan dengan Pendekatan Interactive Conceptual Instruction berbantuan simulasi PhET untuk mengetahui apakah terdapat perbedaan pembelajaran pada kelas kontrol yang menggunakan pembelajaran konvensional dengan metode ceramah dan latihan. Adapun beberpa fitur yang digunakan dalam pendekatan ICI yaitu : (1) Conceptual Focus, (2) Research Based Material (3) Classroom Interaction (4) Use of Texts.

Pada fitur conceptual focus guru menyampaikan konsep-konseo fisika pada materi hukum newton tentang gravitasi, dengan menyampaikan sejarah hukum gravitasi newton dengan menampilkan video, lalu guru menyampaikan fenomena-fenomena yang berkaitan dengan hukum gravitasi newton seperti menjatuhkan dua buah kertas yang bermassa sama namun bentuk berbeda kertas pertama di bentuk bulatan lalu kertas kedua dibiarkan saja, lalu siswa mengamati kertas mana yang jatuh ke tanah lebih dulu, guru memberikan siswa untuk memahami konsep gravitasi dengan menunjukan gejala alam.guru dan siswa menyatakan hukum newton tentang gravitasi bersama. Pada fitur research based material, guru memberikan penguatan materi dengan menampilkan jurnal penelitian mengenai fenomena alam disekitar siswa yang berkaitan tentang gravitasi newton untuk menambah pengetahuan dan pemahaman siswa mengenai Gravitasi Newton, siswa memberikan tanggapan terhadap beberapa penelitian yang telah disampaikan atau dijelaskan oleh guru.

Pada fitur classroom interaction guru membimbing siswa mengidentifikasi masalah yang telah diberikan mengenai fenomena-fenomena yang berkaitan dengan Hukum Gravitasi Newton pada awal pembelajaran, guru menggunakan metode demontrasi untuk menyampaikan Pengaruh Pendekatan Interactive Conceptual Instruction (Ici) Berbantuan Simulasi Phet Terhadap Hasil Belajar Siswa Di Sman 9.... Ega Prastika, Andik Purwanto, Nirwana 
pembelajaran menggunakan simulai $P h E T$, siswa melakukan pengamatan berdasarkan fenomena yang mengandung permasalaahan menggunakan simulasi PhET, beberapa siswa menggunakan simulasi PhET tentang gaya gravitasi, siswa melakukan diskusi terhadap hasil pengamatan (lembar diskusi siswa), dan siswa melakukan Tanya jawab dengan sesame siswa dan guru tentang hasil pengamatan masing-masing kelompok. Terakhir fitur use of text siswa menginterpretasi hasil diskusi dan kemudian mencocokannya dengan pengetahuan yang ada dibuku atau dengan simulai PhET, siswa menyampaikan hasil diskusi mereka apabila terdapat ketidakcocokan pada buku.

Pada kelas kontrol menggunakan model pembelajaran konvensional dengan metode ceramah dan diskusi, guru membuka pembelajaran dengan dengan menggunakan metode ceramah melalui mengapersepsi pembelajaran dan mengaitkannya dengan pembelajaran sebelumnya. Setelah itu, guru mulai memberikan konsep pokok, contoh soal kemudian diskusi kelompok menggunakan lembar diskusi siswa. Pembelajaran juga diselingi dengan tanya jawab dan membuat masing-masing kelompok menjawab soal. Untuk mengetahui hasil belajar siswa digunakan tes yaitu berupa pretest dan posttest. Pada kelas eksperimen dan kelas control masing-masing diberikan pretest untuk menguji kemampuan awal siswa sebelum diberi perlakuan dan diberi soal posttest untuk menguji hasil belajar siswa setelah diberi perlakuan.

Data hasil penelitian pretest dan posttest pada satu kali pertemuan pada kelas eksperimen dapat dilihat pada gambar 1.

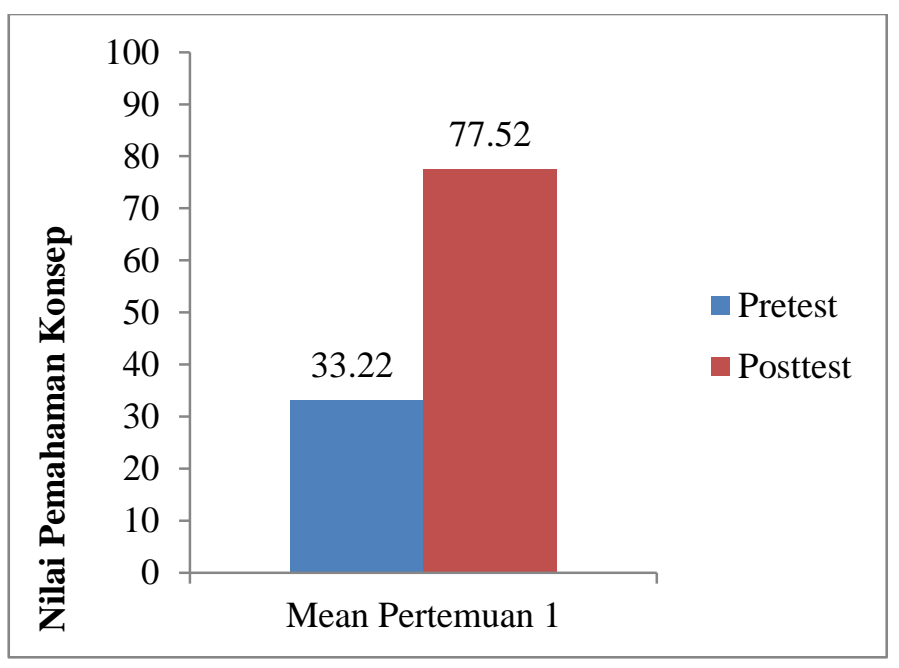

Gambar 1. Grafik Skor Pretest dan Posttest Kelas Eksperimen

Berdasarkan Gambar 1, nilai rata-rata pretest dan posttest kelas eksperimen yang tampilkan, terjadi peningkatan hasil belajar siswa. Hal ini menandakan bahwa pembelajaran dengan menggunakan pendekatan Interactive Conceptual Instruction berbantuan simulasi PhET dapat meningkatkan pemahaman konsep fisika siswa dimana didapatkan rata-rata sebesar 77,52 ini termasuk dalam kategori hasil belajar yang baik, serta pengujian Effect Size yang didapat dapat dikategorikan tinggi. Data yang didapat dalam penelitian ini sejalan dengan enelitian yang berjudul 'Ukuran Pengaruh Pendekatan Interactive Conceptual Instruction Pada Pembelajaran Fisika Untuk Meningkatkan Pemahaman Konsep Usaha Dan Energy Siswa SMA' hasil penelitian ini menunjukkan bahwa pemahaman konsep siswa pada usaha dan energi mengalami peningkatan hal ini diperoleh nilai pengaruh sebesar 1,56 (10). Data hasil penelitian pretest dan posttest juga dilakukan sekali pada kelas control, untuk jelasnya nilai rata-rata prstest dan posttest kelas control disajikan pada gambar 2 . 


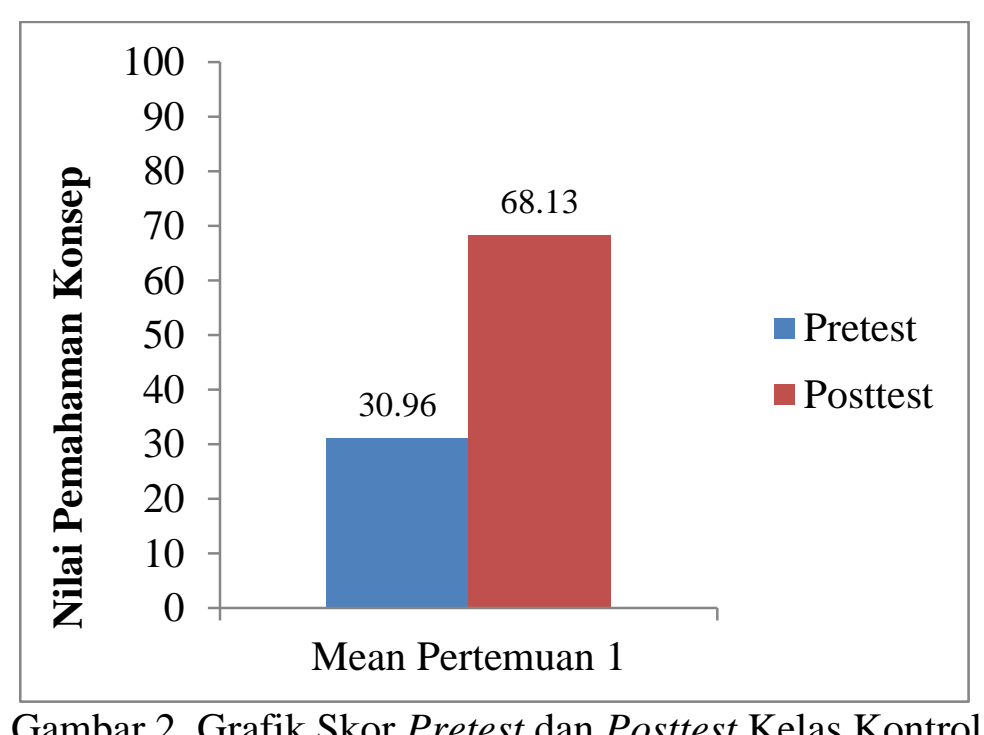

Berdasarkan Gambar 2, nilai Pretest dan posttest rata-rata kelas kontrol pada grafik dapat dilihat juga terjadi peningkatan dengan menggunakan metode konvensional atau ceramah pada kelas kontrol namun belum bisa dikategorikan baik. Hal ini dapat dilihat dari rata-rata kedua pertemuan tes didapat pretest sebesar 30,96 dan rata-rata posttest adalah 68,13 . Dari penjelajasan gambar 1 dan gambar 2, ini sejalan dengan penelitian yang berjudul 'Remediasi Miskonsepsi Siswa Tentang Usaha Menggunakan Pendekatan Konseptual Interaktif Berbantuan Refutation di SMA' hasil penelitian ini menunjukkan bahwa ini sangat efektif untuk memperbaiki miskonsepsi siswa kelas XII SMA Negeri 1 Semparuk pada usaha dengan Effect Size ES=1,67204 (tergolong tinggi) penurunan rata-rata persentase miskonsepsi siswa sebesar 31,79\% (15).

Beberapa hal positif bisa didapatkan dari pembelajaran menggunakan pendekatan Interactive Conceptual Instruction antara lain, siswa dapat mengetahui gejala alam apa saja yang berhubungan dengan gravitasi newton, siswa dapat konsep dari berbagai penelitaian, siswa dapat berinteraksi dengan teman melalui diskus kelompok dan berperan aktif pada saat proses pembelajaran berlangsung, siswa juga membaca buku guna untuk menyimpulkan dari konsep yang ditlah di sampaikan oleh guru maupun yang mereka pahami sendiri apakah sesuai dengan konsep konsep fisika yang selama ini disampaikan dengan buku cetak. Siswa juga dapat mengenal dan mengerti cara memanfaatkan teknologi untuk pembelajaran fisika yaitu berupa simulai $P h E T$.

Pada penelitian ini, siswa kelas eksperimen yang diajarkan menggunakan pendekatan Interactive Conceptual Instruction berbantuan simulasi PhET memiliki rata-rata posttest yang lebih tinggi dari pada kelas kontrol. Pada kelas kontrol siswa diajarkan menggunakan metode konvensional atau metode ceramah sehingga pembelajaran siswa terbatas hanya pada apa yang disampaikan oleh guru. Penjelasan diatas sejalan dengan penelitian yang dilakukan yang berjudul 'Integrasi Remediasi Miskonsepsi Dalam Pembelajaran Dinamis Menggunakan Pendekatan Konseptual Interaktif Di SMA' hasil penelitian ini menunjukkan bahwa Besar persentase penurunan jumlah miskonsepsi tiap siswa setelah diberikan kegiatan integrasi remediasi miskonsepsi dalam pembelajaran fluida dinamis menggunakan pendekatan konseptual interaktif rata-rata sebesar $71,14 \%$; 2) Terdapat perubahan konseptual yang signifikan setelah diberikan kegiatan integrasi remediasi miskonsepsi dalam pembelajaran fluida dinamis menggunakan pendekatan konseptual interaktif yang ditunjukkan dari hasil uji Mc Nemar hitung sebesar 348, 82 (16).

\section{SIMPULAN DAN SARAN}

\subsection{Kesimpulan}

Berdasarkan hasil analisis data penelitian dan pembahasan, kesimpulan yang dapat diambil dari penelitian ini adalah terdapat pengaruh pendekatan interactive conceptual instruction berbantuan simulasi phet terhadap hasil belajar siswa. Hal ini dapat dilihat dari hasil uji-t pada pertemuan satu yang menunjukan bahwa $t_{\text {hitung }}>t_{\text {tabel }}$ atau nilai sig. $(2$-taited $)<5 \%(0,010<0,05)$. 
Sehinga dapat disimpulkan bahwa terdapat pengaruh yang signifikan pembelajaran dengan pendekatan interactive conceptual instruction berbantuan simulasi phet terhadap hasil belajar siswa di SMAN 9 Kota Bengkulu. Besar pengaruh pendekatan interactive conceptual instruction berbantuan simulasi phet terhadap hasil belajar siswa sebesar 0,78 , artinya pendekatan interactive conceptual instruction berbantuan simulasi phet memberikan pengaruh $43 \%$ terhadap hasil belajar siswa.

4.2 Saran

Pembelajaran dengan pendekatan Interactive Conceptual Instruction berbantuan simulasi PhET menggunakan diskusi kelompok yang membutuhkan waktu lama sehingga guru perlu mengatur dan mengelola waktu pelajaran sebaik mungkin.

\section{UCAPAN TERIMA KASIH}

Penulis mengucapkan terimakasih kepada dosen Program Studi Pendidikan Fisika Universitas Bengkulu serta siswa dan guru yang ada di sekolah dan pihak yang telah membantu dan memberikan dukungan baik moriil maupun finansial terhadap penelitian ini.

\section{DAFTAR PUSTAKA}

1. Saat S. FAKTOR-FAKTOR DETERMINAN DALAM PENDIDIKAN (Studi Tentang Makna dan Kedudukannya dalam Pendidikan). J Ta'dib [Internet]. 2015;8(2):1-17. Available from: ejournal.iainkendari.ac.id/al-tadib/article/view/407

2. Kirom A. Peran Guru Dan Peserta Didik Dalam Proses Pembelajaran Berbasis Multikultural. Al Murabbi [Internet]. 2017;3(1):69-80. Available from: http://jurnal.yudharta.ac.id/v2/index.php/pai/article/view/893

3. Sanjaya R. Kuikulum Pembelajaran. Jakarta: Kencana; 2008.

4. Dalam IK. PEMBELAJARAN IPS TERPADU DI SMP NEGERI KOTA SINGKAWANG lingkungan hidup kedua sesudah rumah di mana anak didik sekian jam setiap saat. 2019;6(2):233-41.

5. Tirtarahardja. Pengantar Pendidikan. jakarta: Pt Rineka Cipta.; 2005.

6. Pane A, Darwis Dasopang M. Belajar Dan Pembelajaran. FITRAHJurnal Kaji Ilmu-ilmu Keislam. 2017;3(2):333.

7. Suprihatiningrum. Strategi Pembelajaran. yogyakarta: Ar-Ruzz; 2016.

8. Savinainen A, Scott P. Using the force concept inventory to monitor student learning and to plan teaching. Phys Educ. 2002;37(1):53-8.

9. Handayani R, Studi P, Fisika P, Jember U. Aktualisasi Peran Generasi Milenial Melalui Pendidikan, Pengembangan Sains, dan Teknologi dalam Menyongsong Generasi Emas. 2018;3(2):2527-5917.

10. Rahmaniar A, Suhandi A, Sari M. Ukuran Pengaruh Pendekatan Interactive Conceptual Instruction pada Pembelajaran Fisika untuk Meningkatkan Pemahaman Konsep Usaha dan Energi Siswa SMA. 2015;2015(Snips):261-4.

11. Suhandi A, Sinaga P, Kaniawati I, Suhendi E. Efektivitas Penggunaan Media Simulasi Virtual Pada Pendekatan Pembelajaran Konseptual Interaktif Dalam Meningkatkan Pemahaman Konsep Dan Meminimalkan Miskonsepsi. J Pengajaran Mat dan Ilmu Pengetah Alam. 2009;13(1):35. 
12. Sugiono. Metode Penelitian Pendidikan. bandung: Alfabeta; 2010.

13. Sugiono. Metode Penliitian Kuantitatif, Kualitatif Dan R\&D. bandung: Alfabeta; 2018.

14. Diani R, Yuberti Y, Syafitri S. Uji Effect Size Model Pembelajaran Scramble dengan Media Video Terhadap Hasil Belajar Fisika Peserta Didik Kelas X MAN 1 Pesisir Barat. J Ilm Pendidik Fis Al-Biruni. 2016;5(2):265.

15. Djudin T, S HTM. Remediasi miskonsepsi siswa tentang usaha menggunakan pendekatan konseptual interaktif berbantuan refutation text di sma. 48:1-11.

16. Sma DI, Sma DI. Artikel Penelitian Oleh : Kurnia Sari Integrasi Remediasi Miskonsepsi Dalam Pembelajaran Fluida. 2018; 